\title{
The Role of Pragmatic Constraints in the Processing of Analogous Cross-Mapping Situations
}

T. Ripoll, L. Bourrelly, F. Antoni and A. Pélissier

\section{(2) OpenEdition}

1 Journals

\section{Electronic version}

URL: http://journals.openedition.org/cpl/105

DOI: $10.4000 / \mathrm{cpl} .105$

ISSN: $1379-6100$

\section{Publisher}

Centre PsyCLÉ

\section{Printed version}

Date of publication: 1 April 2000

\section{Electronic reference}

T. Ripoll, L. Bourrelly, F. Antoni and A. Pélissier, «The Role of Pragmatic Constraints in the Processing of Analogous Cross-Mapping Situations », Current psychology letters [Online], 2000/1, 1 | 2000, Online since 04 September 2003, connection on 08 September 2020. URL : http://journals.openedition.org/ cpl/105; DOI : https://doi.org/10.4000/cpl.105

This text was automatically generated on 8 September 2020.

(C) All rights reserved 
The Role of Pragmatic Constraints in the Processing of Analogous Cross-Mapping Situations

T. Ripoll, L. Bourrelly, F. Antoni and A. Pélissier 